\title{
Incidence and Associated Risk Factors of Chemotherapy-Induced Cardiomyopathy in the African American and Afro-Caribbean Populations
}

Mohammed Al-Sadawi ${ }^{1}$, Kurnvir Singh ${ }^{1}$, Violeta Capric ${ }^{1}$, Amena Mohiuddin ${ }^{1}$, Michael Haddadin ${ }^{1}$, Arismendy Nunez ${ }^{2}$, Shakil Shaikh ${ }^{2}$, Inna Bukharovich ${ }^{3}$ and Samy I. McFarlane ${ }^{1, *}$

${ }^{1}$ Department of Internal Medicine, State University of New York: Downstate Medical Center, Brooklyn, NY 11203, United States-

${ }^{2}$ Department of Cardiovascular Medicine, State University of New York: Downstate Medical Center, Brooklyn, NY 11203, United States

${ }^{3}$ Department of Cardiovascular Medicine, Kings County Hospital Center, Brooklyn, NY 11203, United States

\section{Abstract}

\section{Publication History:}

Background: Chemotherapy-induced cardiomyopathy (CICM) and heart failure are major complications of cancer therapeutics and can result in significant morbidity and mortality. There is limited data on the incidence and risk factors of CICM in African American and Afro-Caribbean patients.

Received: November 19, 2020

Accepted: December 12, 2020

Methods: We performed a retrospective chart review to evaluate the baseline characteristics that may predispose to CICM. Patients were African American and Afro-Caribbean ethnicity. Data was collected between 2014 to 2018. Patients had transthoracic echocardiogram (TTE) or multigated acquisition scan (MUGA) prior to cancer therapy and every 3 months thereafter, until the end of the regimen. CICM was defined as a $\geq 16 \%$ reduction in LVEF or $\geq 10 \%$ reduction in LVEF to a value $<50 \%$.

Results: A total of 230 patients were studied, with a mean age of $54 \pm 12$ years with $91 \%$ were females, Published: December 14, 2020

\section{Keywords:}

Echocardiography, Function, EndBMI $30 \pm 4,81 \%$ were taking anthracyclines, $87 \%$ were on Trastuzumab while $5 \%$ were receiving both medications. The prevalence of comorbidities was as follows: hypertension $8 \%$, diabetes mellitus $8 \%$, ESRD $8 \%$, dyslipidemia $8 \%$, CAD 7\%. The incidence of CICM was $7 \%$ overall, while it was $6 \%$ and $8 \%$ for patients taking Anthracyclines and Trastuzumab, respectively. CICM was associated with dyslipidemia $(\mathrm{r}=.22, \mathrm{p}=.001)$, hypertension $(\mathrm{r}=.12, \mathrm{p}=.05)$, baseline ejection fraction $(\mathrm{r}=-.21, \mathrm{p}=.001)$ and concomitant use of radiation therapy $(\mathrm{r}=.147, \mathrm{p}=.02)$, but not with age, gender, beta blocker use, angiotensin converting enzyme inhibitor use, number of chemotherapy cycles or stage of the malignancy. On multivariate analysis CICM was independently associated with baseline ejection fraction $(\beta=-.193$, $\mathrm{P}=.003)$ and dyslipidemia $(\beta=-.20, \mathrm{P}=.003)$.

Conclusion: The incidence of CICM in African Americans and Afro-Caribbean is higher than reported in the general population. Dyslipidemia and baseline ejection fraction were seen as the major risk factors associated with the higher incidence of CICM.

\section{Introduction}

Through new advances in chemotherapy, survival of cancer patients has dramatically increased over the years. However, as their use has become more generalized, the incidence of side effects has become more apparent. One such side effect is the development of cardiotoxicity. Cardiotoxicity is particularly a concern with the use of HER2 blockers Trastuzumab and Antracyclines. Despite the risk of cardiac dysfunction or cardiomyopathy, targeted therapies have revolutionized the treatment of cancer, specifically in HER2 positive breast cancer. Medications, such as trastuzumab, have shown better response, longer time to disease progression, and longer survival in historically aggressive cancers, thus making their utilization desired [1]. The range of adverse cardiac manifestations of these medications include QT prolongation, arrhythmias, myocardial ischemia and/or infarction (seen in patients receiving radiation), hypertension, venous and arterial thromboembolism (seen with the anti-angiogenic agents: bevacizumab, sorafenib, sunitinib, and pazopanib), and congestive heart failure (HF) (seen commonly with anthracyclines and also with monoclonal antibodies and targeted therapies) [2].

Historically chemotherapy induced cardiomyopathy (CICM) has been classified into two types; type I, which often refers to permanent damage to the myocardium, and type 2, which encompasses all types of reversible cardiomyopathy [1]. Typically, anthracyclines, such as doxorubicin, are known to cause a type I CM, and monoclonal antibodies and targeted therapies, such as hertuzumab, are known to cause a type $2 \mathrm{CM}$.

According to the European Society of Cardiology (ESC) Guidelines for heart failure, heart failure has been classified into three groups: reduced ejection fraction $(\mathrm{EF})<40 \%$, mid-range $\mathrm{EF}$ $40-49 \%$ and preserved $\mathrm{EF}>50 \%$. A fourth group of heart failure encompasses patients that have improved EF after stopping the inciting chemotherapy agent, however guidelines regarding duration of treatment and monitoring in these patients remain lacking. When focusing specifically on chemotherapy induced HF, however, the ESC mentions that a reduction in EF from baseline is needed for the diagnosis [3]. Alternatively, the clinical trials surrounding trastuzumab, define CICM as a decline in left ventricular ejection fraction (LVEF) of at least $5 \%$ or less than $55 \%$ in symptomatic

*Corresponding Author: Prof. Samy I. McFarlane, College of Medicine, Department of Medicine, Division of Endocrinology, Internal Medicine Residency Program Director, State University of New York, Downstate Medical Center, 450 Clarkson Ave, Box 50, Brooklyn, New York, 11203-2098, USA. Phone 718-2706707, Fax 718-270-4488; E-mail: smcfarlane@downstate.edu

Citation: Al-Sadawi M, Singh K, Capric V, Mohiuddin A, Haddadin M, et al. (2020) Incidence and Associated Risk Factors of Chemotherapy-Induced Cardiomyopathy in the African American and Afro-Caribbean Populations. Int J Clin Res Trials 5: 154. doi: https://doi.org/10.15344/2456-8007/2020/154

Copyright: (C) 2020 Al-Sadawi et al. This is an open-access article distributed under the terms of the Creative Commons Attribution License, which permits unrestricted use, distribution, and reproduction in any medium, provided the original author and source are credited. 
Citation: Al-Sadawi M, Singh K, Capric V, Mohiuddin A, Haddadin M, et al. (2020) Incidence and Associated Risk Factors of Chemotherapy-Induced Cardiomyopathy in the African American and Afro-Caribbean Populations. Int J Clin Res Trials 5: 154. doi: https://doi.org/10.15344/2456-8007/2020/154

Page 2 of 6

patients or a decline of LVEF of $10 \%$ or less than $55 \%$ in those without symptoms. Despite no clear consensus on definition, reductions in EF of about $10 \%$ from baseline following initiation of chemotherapy and the development of symptomology are significant and warrant investigation before continuation of therapy [4].

Heart failure or any cardiotoxicity may present in patients acutely, sub acutely, chronically or late-occurring [1]. Anthracycline induced cardiotoxicity can cause a range of cardiac effects; however, it is important to recognize that late-occurring cardiotoxicity may not become apparent up until 20 years after the first dose of chemotherapy [4]. Thus, posing a risk of CICM in a large subset of patients who may currently be asymptomatic.

The mechanism for chemotherapy agents to induce cardiomyopathy has been hypothesized for various chemotherapy agents. For anthracyclines it is believed that oxidative stress causing myocardial cell death and apoptosis is the cause of irreversible cardiac dysfunction [5]. The damage caused by anthracyclines is dose dependent related to each individual dose administered and cumulative dose received in a patient's lifetime, however risk of CICM increases with concurrent mediastinal radiation, increasing age, female gender, and cardiac disease [6]. For HER2 agents it is thought that disrupting cell repair pathways causes a reversible cardiomyopathy [7]. Additional risk factors for developing cardiotoxicity from trastuzumab include a diagnosis of diabetes, age, decreased glomerular filtration rate, use of anti-hypertensives and a history of cardiac disease [8]. These risk factors, however, are not uniform. One study showed that African American race alone was associated with a 3 times greater risk of developing CICM in patients who had completed anthracycline therapy, while another study showed a similar increase in risk of CICM in African American women one year after completion of trastuzumab therapy $[9,10]$. Not only do African American patients have an increased risk of developing CICM compared to their white counterparts, but also, have increased risk of not completing a course of chemotherapy due to the development of LVD [11]. Recognizing additional risk factors for the development of cardiomyopathy is important as it may facilitate in identifying high-risk patients that may benefit from more frequent follow up and early intervention.

Patients receiving trastuzumab and/or anthracyclines should be monitored for the development of cardiomyopathy especially due to an increased risk of CICM when combining the two therapies. The incidence of CICM up to five years after completion of therapy in patients using trastuzumab alone is about $10 \%$ and in combination with anthracyclines is up to $20 \%[12,13]$. Biomarkers, including troponin, and the development of global strain on echocardiograms may be used in order to detect subclinical LV dysfunction sooner than when patients become symptomatic $[14,15]$. The goal of early detection is early treatment. Current guidelines recommend that once LVD of greater than $10 \%$ change from baseline is noted, chemotherapy should be held and patients should be initiated on ACE inhibitors and beta blockers. Follow up echocardiograms should be performed thereafter at set intervals to monitor for improvement of EF [4]. Some studies have demonstrated that LV dysfunction was potentially reversible depending on the time to treatment with ACE inhibitors and beta blockers. Therefore, identifying high risk patients becomes all the more important [16].

Despite, the growing recognition of CICM, more research needs to be done in order to risk stratify patients and understand which patients require closer monitoring. Research has already shown the African Americans have a greater predisposition for developing CICM, however further stratification of modifiable risk factors is necessary in order to potentially prevent the occurrence of CICM in this subset population. Here, we assess the effects of various chemotherapy agents on CICM in a largely afro-Caribbean and African American population.

\section{Methods}

\section{Data collection}

We conducted a retrospective chart review of electronic medical records of individuals who were diagnosed with breast cancer and received neoadjuvant or adjuvant anthracycline, trastuzumab with or without pertuzumab between January 2014 and December 2018 at our facility in Brooklyn, New York. It is a tertiary hospital in Brooklyn that serves a community with a majority of African American and Afro-Caribbean patients.

Data collection included basic demographic characteristics: age, gender, race, weight, height, and body mass index; malignancy characteristics: stage, grade, HER2 receptor status, treatment with radiation therapy, type of chemotherapy, duration of chemotherapy, follow up in months; cardiovascular co-morbidities: diabetes, hypertension, dyslipidemia, obstructive sleep apnea, smoking status, chronic obstructive pulmonary disease and chronic kidney disease; cardiac imaging data was mainly from multigated acquisition scan (MUGA) or/and transthoracic echocardiogram (TTE); and cardiovascular-related or antihypertensive medications: angiotensin receptor blockers, angiotensin converting enzyme inhibitors, beta blockers, calcium channel blockers, hydralazine, nitrates, digoxin, and anti-arrhythmic medications.

At our facility, the protocol for a cancer patient who is going to receive chemotherapy regimen known to cause cardiotoxicity, as in anthracycline-based and trastuzumab-based therapy, is as follows: to have a cardiac imaging study (primarily MUGA scan)to monitor for cardiomyopathy before starting therapy and every three months until the end of therapy. As a result, most of our data during patient follow up is from MUGA scan results.

Exclusion criteria included patients who did not receive anthracycline-based, trastuzumab-based or pertuzumab-based therapy, lost follow up, discontinued therapy secondary to psychosocial reasons, switch care to another facility.

Cardiac evaluation was based on left ventricular ejection fraction (LVEF), which was obtained mainly from MUGA scans and/or TTE. Chemotherapy-induced cardiotoxicity was defined as a $\geq 16 \%$ reduction in LVEF or $\geq 10 \%$ reduction in LVEF to a value $<50 \%$ [12].

\section{Statistical analysis}

Demographics, tumor-related clinical data and cardiovascular co-morbidities were analyzed using descriptive statistics. Univariate associations between study variables were analyzed using Spearman's correlation coefficients. Continuous data was compared using either Student's t-test. Chi square was used to assess differences between dichotomous variables. Independent associations were determined by multivariate linear regression. Statistical analyses were performed using the Statistical Package for Social Sciences (SPSS) software version 24 (SPSS Inc., Chicago, Ill., USA). A p value $<0.05$ was considered statistically significant. 
Citation: Al-Sadawi M, Singh K, Capric V, Mohiuddin A, Haddadin M, et al. (2020) Incidence and Associated Risk Factors of Chemotherapy-Induced Cardiomyopathy in the African American and Afro-Caribbean Populations. Int J Clin Res Trials 5: 154. doi: https://doi.org/10.15344/2456-8007/2020/154

Page 3 of 6

\section{Results}

We screened 420 patients and 110 patients were excluded in the basis of exclusion criteria, the remaining identified 310 African American and Afro-Caribbean were included in the study. The mean age was $54 \pm 12$ years. In total, $91 \%$ were females. BMI was $30 \pm 4$. In our cohort, $81 \%$ were taking anthracyclines, $87 \%$ were on Trastuzumab while $5 \%$ were receiving both medications. The prevalence of cardiovascular comorbidities was as follows: hypertension $8 \%$, diabetes mellitus $8 \%$, ESRD 8\%, dyslipidemia 8\%, CAD 7\%. Mean follow up in months was $26 \pm 17$ and the mean number of chemotherapy cycles was $9 \pm 6$.

The incidence of CICM was $7 \%$ overall, while it was $6 \%$ and $8 \%$ for patients taking Anthracyclines and Trastuzumab, respectively. CICM was associated with dyslipidemia $(\mathrm{r}=.22, \mathrm{p}=.001)$, hypertension $(\mathrm{r}=.12, \mathrm{p}=.05)$, baseline ejection fraction $(\mathrm{r}=-.21, \mathrm{p}=.001)$ and concomitant use of radiation therapy $(\mathrm{r}=.147, \mathrm{p}=.02)$. However, CICM was not statistically significant with regards to age, gender, beta blocker use, angiotensin converting enzyme inhibitor use, number of chemotherapy cycles or stage of the malignancy. On multivariate analysis CICM was independently associated with baseline ejection fraction $(\beta=-.193, \mathrm{P}=.003)$ and dyslipidemia $(\beta=-.20, \mathrm{P}=.003)$.

\section{Discussion}

Anthracyclines and HER2 receptor antagonists are an integral part of chemotherapy regimens used to treat breast cancer. These medications are highly effective in the treatment of breast cancer $[17,18]$. Although, anthracyclines and HER2 receptor antagonists are generally well tolerated, their potential to cause cardiotoxicity has been well documented. Even though the mechanism and prognosis of cardiotoxicity may differ between anthracyclines and HER2 receptor antagonists, the result can often lead to significant morbidity and mortality. There is also extremely limited data on the racial disparities in the development of cardiotoxicity with both anthracycline and HER2 receptor antagonists [19]. The aim of this study was characterizing the incidence and risk factors contributing to chemotherapy induced cardiomyopathy among a primarily African American and AfroCaribbean population.

The pathogenesis of trastuzumab mediated cardiomyopathy is most likely mediated by the blockage of HER2 receptor signals in cardiac myocytes. This would prevent the transmission of the cascade essential for myocyte repair, resulting in myocyte apoptosis and necrosis [20]. Studies have shown that the left ventricular dysfunction from trastuzumab can be reversible after withdrawal and does not appear to be dose dependent [21]. The incidence range in the literature appears to be between $2.0-28.0 \%$. Table 1 shows a compiled list of studies with their protocol and incidence listed. Each study had its own parameters and design likely accounting for the differences in measured incidence. For example, each study had a different population with variable patient characteristics, with a variable definition of trastuzumab-induced cardiotoxicity. Many studies also used the less accurate echocardiogram, which is not only user dependent, but also may have variable readings and interpretations. Lastly, patient characteristics, such as the use of anthracyclines prior to adjuvant trastuzumab treatment, have also been shown to increase the risk for the development of trastuzumab-mediated cardiomyopathy in a dose dependent manner [22].

\begin{tabular}{|c|c|c|c|c|c|c|}
\hline Study & $\begin{array}{l}\text { Number of } \\
\text { Patients }\end{array}$ & $\begin{array}{l}\text { Type of Breast } \\
\text { Cancer }\end{array}$ & $\begin{array}{l}\text { Number of } \\
\text { weeks of } \\
\text { Trastuzumab }\end{array}$ & $\begin{array}{l}\text { Used anthracyclines } \\
\text { prior to Trastuzumab }\end{array}$ & $\begin{array}{l}\text { Definition of } \\
\text { Cardiomyopathy }\end{array}$ & $\begin{array}{l}\text { Incidence of } \\
\text { trastuzumab-mediated } \\
\text { Cardiotoxicity }\end{array}$ \\
\hline $\begin{array}{l}\text { Vogel et al. } \\
\text { (2002) [25] }\end{array}$ & 114 & $\begin{array}{l}\text { HER2-positive } \\
\text { metastatic breast } \\
\text { cancer }\end{array}$ & $\begin{array}{l}\text { Median } 16 \\
\text { weeks }\end{array}$ & $\begin{array}{l}2 / 3 \text { patients developing } \\
\text { TMC }\end{array}$ & $\begin{array}{l}\text { CHF symptoms, } \\
\text { Cardiomyopathy, or } \\
\text { a decrease in ejection } \\
\text { fraction by } 10 \%\end{array}$ & $2 \%$ \\
\hline $\begin{array}{l}\text { Guarneri et } \\
\text { al. (2006) } \\
{[26]}\end{array}$ & 218 & $\begin{array}{l}\text { HER2-positive } \\
\text { metastatic breast } \\
\text { cancer }\end{array}$ & $\begin{array}{l}\text { Median } 21.3 \\
\text { months }\end{array}$ & $\begin{array}{l}85 \% \text { of TIC had prior } \\
\text { anthracycline exposure }\end{array}$ & $\begin{array}{l}\text { LVEF decreasing below } \\
50 \%,>20 \% \text { drop in LVEF, } \\
\text { or symptoms of CHF }\end{array}$ & $28 \%$ \\
\hline $\begin{array}{l}\text { Suter et al. } \\
\text { (2007) [27] }\end{array}$ & 1,693 & $\begin{array}{l}\text { HER2-positive } \\
\text { early invasive breast } \\
\text { Caner }\end{array}$ & $\begin{array}{l}12 \text { or } 24 \\
\text { months }\end{array}$ & $\begin{array}{l}94 \% \text { had adjuvant } \\
\text { anthracycline based } \\
\text { therapy }\end{array}$ & $\begin{array}{l}\text { LVEF decreasing below } \\
50 \%,>10 \% \text { drop in LVEF, } \\
\text { or symptoms of CHF }\end{array}$ & $4.3 \%$ \\
\hline $\begin{array}{l}\text { Perez et al. } \\
\text { (2008) [28] }\end{array}$ & 1,944 & $\begin{array}{l}\text { HER2-positive } \\
\text { node-positive or } \\
\text { high-risk node } \\
\text { negative invasive } \\
\text { breast cancer }\end{array}$ & 52 weeks & $\begin{array}{l}\text { All arms treated } \\
\text { with Doxorubicin + } \\
\text { cyclophosphamide } \\
\text { (AC) prior }\end{array}$ & $\begin{array}{l}\text { decreased }>15 \% \text { points } \\
\text { from baseline, decreased } \\
\text { below } 50 \% \text {, or symptoms } \\
\text { of CHF }\end{array}$ & $\begin{array}{l}\text { Arm A: AC then } \\
\text { Paclitaxel: } 0.3 \% \\
\text { Arm B: AC then } \\
\text { Paclitaxel then } \\
\text { trastuzumab: } 2.8 \% \text {, } \\
\text { Arm C: AC + Paclitaxel } \\
\text { with trastuzumab: } 3.3 \%\end{array}$ \\
\hline $\begin{array}{l}\text { Gianni et al. } \\
\text { (2010) [18] }\end{array}$ & 117 & $\begin{array}{l}\text { HER2-positive } \\
\text { locally advanced or } \\
\text { inflammatory breast } \\
\text { cancer }\end{array}$ & 52 weeks & $\begin{array}{l}\text { neoadjuvant } \\
\text { trastuzumab } \\
\text { plus concurrent } \\
\text { doxorubicin-including } \\
\text { chemotherapy }\end{array}$ & $\begin{array}{l}\text { Development of EF } \\
<50 \%\end{array}$ & $2 \%$ \\
\hline $\begin{array}{l}\text { Untch et al. } \\
\text { (2010) [29] }\end{array}$ & 120 & $\begin{array}{l}\text { HER2-positive } \\
\text { metastatic breast } \\
\text { cancer }\end{array}$ & 39-45 weeks & $\begin{array}{l}\text { trastuzumab } \\
\text { plus concurrent } \\
\text { epirubicin -including } \\
\text { chemotherapy }\end{array}$ & $\begin{array}{l}\text { Decrease in LVEF of } \\
\text { more than } 10 \% \text { to less } \\
\text { than } 50 \%\end{array}$ & $\begin{array}{l}\text { Arm with trastuzumab } \\
+ \text { epirubicin } 60 \mathrm{mg} / \mathrm{m} \text { : } \\
1.7 \% \text {, } \\
\text { Arm with trastuzumab } \\
+ \text { epirubicin } 90 \mathrm{mg} / \mathrm{m}: \\
5.0 \%\end{array}$ \\
\hline
\end{tabular}

Continue. 
Citation: Al-Sadawi M, Singh K, Capric V, Mohiuddin A, Haddadin M, et al. (2020) Incidence and Associated Risk Factors of Chemotherapy-Induced Cardiomyopathy in the African American and Afro-Caribbean Populations. Int J Clin Res Trials 5: 154. doi: https://doi.org/10.15344/2456-8007/2020/154

Page 4 of 6

\begin{tabular}{|c|c|c|c|c|c|c|}
\hline $\begin{array}{l}\text { Slamon et } \\
\text { al. }(2011) \\
{[30]}\end{array}$ & 3222 & $\begin{array}{l}\text { HER2-positive, } \\
\text { node-negative } \\
\text { or node-positive } \\
\text { adenocarcinoma }\end{array}$ & 52 weeks & $\begin{array}{l}\text { 1)doxorubicin and } \\
\text { cyclophosphamide } \\
\text { followed by docetaxel } \\
\text { every } 3 \text { weeks (AC-T) } \\
\text { 2) the same regimen } \\
\text { plus } 52 \text { weeks of } \\
\text { trastuzumab (AC-T } \\
\text { plus trastuzumab) } \\
\text { 3) or docetaxel and } \\
\text { carboplatin plus } 52 \\
\text { weeks of trastuzumab } \\
\text { (TCH) }\end{array}$ & $\begin{array}{l}\text { Decrease in LVEF of } \\
\text { more than } 10 \% \text { from } \\
\text { baseline }\end{array}$ & $\begin{array}{l}\text { 1) AC-T } 11.2 \\
\text { 2) AC-T plus } \\
\text { Trastuzumab } 18.6 \\
\text { 3) TCH } 9.4\end{array}$ \\
\hline $\begin{array}{l}\text { Romond, et } \\
\text { al. (2012) } \\
{[31]}\end{array}$ & 944 & $\begin{array}{l}\text { Node Positive, } \\
\text { HER2 Positive } \\
\text { Breast Cancer }\end{array}$ & 52 weeks & $\begin{array}{l}\text { Use of trastuzumab } \\
\text { after } 4 \text { cycles of } \\
\text { doxorubicin- containing } \\
\text { chemotherapy }\end{array}$ & $\begin{array}{l}\text { decrease of } L V E F> \\
10 \% \text { from baseline to a } \\
\text { value less than } 55 \% \text { OR } \\
\text { decrease of more than } 5 \% \\
\text { to a value below } 50 \%\end{array}$ & $\begin{array}{l}4.0 \%(95 \% \mathrm{CI}, 2.8 \% \\
\text { to } 5.2 \%) \text { vs } 1.3 \%(95 \% \\
\text { CI, } 0.5 \% \text { to } 2.1 \%) \text { in } \\
\text { control arm }\end{array}$ \\
\hline $\begin{array}{l}\text { Azambuja } \\
\text { et al. (2014) } \\
{[32]}\end{array}$ & $\begin{array}{l}1,673 \\
\text { In } 1 \text { year } \\
\text { arm and } \\
1,682 \text { in } \\
\text { two year } \\
\text { arm }\end{array}$ & $\begin{array}{l}\text { HER2-positive } \\
\text { Early Stage Breast } \\
\text { cancer }\end{array}$ & $\begin{array}{l}52 \text { or } 102 \\
\text { weeks }\end{array}$ & $\begin{array}{l}94 \% \text { of patients received } \\
\text { an anthracycline-based } \\
\text { chemotherapy prior }\end{array}$ & $\begin{array}{l}\text { decline of at least } 10 \\
\text { percentage points from } \\
\text { baseline LVEF and a } \\
\text { decline to less than } 50 \%\end{array}$ & $\begin{array}{l}9.4 \% \text { of patients in } \\
\text { the } 2 \text {-year arm and } \\
5.2 \% \text { of patients in the } \\
1 \text {-year arm }\end{array}$ \\
\hline $\begin{array}{l}\text { Advani, et } \\
\text { al. }(2016) \\
{[33]}\end{array}$ & 1876 & $\begin{array}{l}\text { Node positive or } \\
\text { high-risk node } \\
\text { negative breast } \\
\text { cancer }\end{array}$ & 52 Weeks & $\begin{array}{l}\text { Arm A: AC followed by } \\
\text { weekly paclitaxel; Arm } \\
\text { B: paclitaxel then } 52 \\
\text { weeks of trastuzumab; } \\
\text { Arm C: paclitaxel } \\
\text { plus } 52 \text { weeks of } \\
\text { trastuzumab followed } \\
\text { by trastuzumab alone }\end{array}$ & $\begin{array}{l}\text { LVEF decreased by } \\
\text { greater than } 15 \% \text { points } \\
\text { or to } 10 \% \text { to } 15 \% \text { points } \\
\text { below } 50 \%\end{array}$ & $\begin{array}{l}\text { Arm A: } 0.6 \% \text { Arm B: } \\
2.8 \% \text { Arm C: } 3.4 \%\end{array}$ \\
\hline $\begin{array}{l}\text { Yoon, et al. } \\
(2016)[34]\end{array}$ & 712 & Breast cancer & 52 weeks & $\begin{array}{l}\text { anthracycline-based } \\
\text { treatment prior }\end{array}$ & $\begin{array}{l}\text { LVEF of }<55 \% \text { or the } \\
\text { decrease in LVEF of } \\
>10 \% \text { from the baseline } \\
\text { LVEF }\end{array}$ & $11.4 \%$ \\
\hline $\begin{array}{l}\text { Dang, et al. } \\
(2017) \text { [35] }\end{array}$ & 406 & $\begin{array}{l}\text { Node Negative, } \\
\text { HER2 Positive } \\
\text { Breast Cancer }\end{array}$ & 52 weeks & No anthracycline & $\begin{array}{l}\text { decrease of } 10-15 \% \text { in } \\
\text { LVEF }\end{array}$ & $\begin{array}{l}3.2 \%(95 \% \text { CI: } 1.9- \\
5.4 \%)\end{array}$ \\
\hline $\begin{array}{l}\text { Cameron et } \\
\text { al. }(2017) \\
{[21]}\end{array}$ & 5102 & $\begin{array}{l}\text { Node positive or } \\
\text { high-risk node } \\
\text { negative breast } \\
\text { cancer }\end{array}$ & $\begin{array}{l}52 \text { weeks or } \\
104 \text { weeks }\end{array}$ & $\begin{array}{l}94 \% \text { received an } \\
\text { anthracycline-based } \\
\text { chemotherapy prior }\end{array}$ & $\begin{array}{l}\text { LVEF drop of at least } \\
10 \text { percentage points } \\
\text { from baseline and to an } \\
\text { absolute LVEF below } 50 \% \\
\text { or cardiac death. }\end{array}$ & $\begin{array}{l}7.3 \% \text { in the } 2 \text {-years } \\
\text { trastuzumab group, } \\
4.4 \% \text { in the } 1 \text {-year } \\
\text { trastuzumab group, } \\
\text { and } 0.9 \% \text { in the } \\
\text { observation group. }\end{array}$ \\
\hline
\end{tabular}

Table 1: Incidence of trastuzumab-mediated Cardiotoxicity in Several Trials.

Our study has found an incidence of trastuzumab-mediated cardiomyopathy of $8 \%$, which is higher than most documented studies. A subgroup analysis of races was seldom done in the randomized controlled trials. The HERA trial stratified data according to race, but was underpowered as only 20 out of 4482 patients were African American [23]. Litvak et al. conducted a retrospective chart review studying the rate of cardiotoxicity of HER2-targeted therapies among women with early breast cancer with a focus on racial disparities. The study found a cardiotoxicity rate at 1 year to be $12.5 \%$ in all study patients, with African American females at $24 \%$ and Caucasian females to be at 7\% [19]. Rugo et al. conducted a observational study and found the incidence of cardiac safety events (grade $\geq 3$ ) to be higher in black patients $(10.9 \%)$ than in white patients $(7.9 \%)$ who were receiving trastuzumab for with HER2-positive metastatic breast cancer [24].

Anthracycline induced cardiomyopathy (AIC) has been well documented with the pathogenesis possibly involving the formation of anthracycline-iron complexes with subsequent free-radical formation resulting in myocyte damage [36]. Anthracycline induced cardiomyopathy seems to be dose dependent and usually reversible $[22,37]$. The exact incidence is also difficult to establish as studies have variable dosing protocols and designs. Table 2 shows a compiled list of studies with their protocol and incidence listed. Swain et al. studied doxorubicin, reporting a $5 \%$ AIC at $400 \mathrm{mg} / \mathrm{m}^{2}, 16 \%$ at $500 \mathrm{mg} / \mathrm{m}^{2}$, $26 \%$ at a dose of $550 \mathrm{mg} / \mathrm{m}^{2}$, and $48 \%$ at a dose of $700 \mathrm{mg} / \mathrm{m}^{2}$ [22]. Very few studies have stratified data by race for AIC. Hasan et al. studied doxorubicin induced cardiomyopathy and found a dose dependent development of cardiotoxicity and found that African Americans had a higher rate of cardiotoxicity with doxorubicin therapy (7/100 cases) when compared with a similar retrospective study of 399 patients of undifferentiated racial distribution (10/399 cases) [38]. Our study of primarily African American and Afro-Caribbean patients found a AIC incidence of $6 \%$. This seems to be in accordance with previous AIC studies. 
Citation: Al-Sadawi M, Singh K, Capric V, Mohiuddin A, Haddadin M, et al. (2020) Incidence and Associated Risk Factors of Chemotherapy-Induced Cardiomyopathy in the African American and Afro-Caribbean Populations. Int J Clin Res Trials 5: 154. doi: https://doi.org/10.15344/2456-8007/2020/154

Page 5 of 6

\begin{tabular}{|c|c|c|c|c|c|c|}
\hline Study & Anthracycline & $\begin{array}{l}\text { Number } \\
\text { of Patients }\end{array}$ & $\begin{array}{l}\text { Type of Breast } \\
\text { Cancer }\end{array}$ & $\begin{array}{l}\text { Cumulative Dose } \\
\text { Administered }\end{array}$ & $\begin{array}{l}\text { Definition of } \\
\text { Cardiomyopathy }\end{array}$ & $\begin{array}{l}\text { Incidence of } \\
\text { anthracycline-mediated } \\
\text { Cardiotoxicity }\end{array}$ \\
\hline $\begin{array}{l}\text { Jensen et al. } \\
(2002)[39]\end{array}$ & epirubicin & 120 & $\begin{array}{l}\text { recurrent } \\
\text { metastatic breast } \\
\text { cancer }\end{array}$ & $1000 \mathrm{mg} / \mathrm{m}^{2}$ epirubicin, & $\begin{array}{l}\text { Clinical symptoms of } \\
\text { CHF or decline in LVEF }\end{array}$ & $\begin{array}{l}15 \% \text { of the patients } \\
\text { experienced a } 25 \% \\
\text { relative reduction in } \\
\text { LVEF } 3 \text { weeks after } \\
\text { terminating therapy, } \\
\text { increasing to } 59 \% \text { after } \\
3 \text { years }\end{array}$ \\
\hline $\begin{array}{l}\text { Swain et al. } \\
(2003)[22]\end{array}$ & doxorubicin & 630 & $\begin{array}{l}\text { breast carcinoma } \\
\text { and small cell } \\
\text { lung carcinoma }\end{array}$ & $400-700 \mathrm{mg} / \mathrm{m}^{2}$ & $\begin{array}{l}\text { Drop } \geq 20 \% \text { in LVEF } \\
\text { from baseline, drop } \\
\geq 10 \% \text { in LVEF from } \\
\text { baseline and to below } \\
\text { the institution's LLN, or } \\
\text { clinical symptoms of CHF }\end{array}$ & $\begin{array}{l}5 \% \text { at } 400 \mathrm{mg} / \mathrm{m} 2,16 \% \text { at } \\
500,26 \% \text { at a dose of } 550 \\
\mathrm{mg} / \mathrm{m} 2,48 \% \text { at a dose of } \\
700 \mathrm{mg} / \mathrm{m} 2,\end{array}$ \\
\hline $\begin{array}{l}\text { Azambuja et } \\
\text { al. (2009)[40] }\end{array}$ & Epirubicin & 777 & $\begin{array}{l}\text { Node-Positive } \\
\text { Breast Cancer }\end{array}$ & $\begin{array}{l}\text { EC: epirubicin } 60 \mathrm{mg} / \mathrm{m}^{2} \\
\text { with cyclophosphamide } \\
\text { or HEC: epirubicin } \\
100 \mathrm{mg} / \mathrm{m}^{2} \text { with } \\
\text { cyclophosphamide }\end{array}$ & $\begin{array}{l}\text { Drop of LVEF }<50 \% \text { or } \\
\text { clinical symptoms of CHF }\end{array}$ & $\begin{array}{l}\mathrm{EC}, \mathrm{n}=.64 \%(5 / 777) \\
\mathrm{HEC}, \mathrm{n}=1.4 \%(11 / 777)\end{array}$ \\
\hline $\begin{array}{l}\text { Ryberg et al. } \\
(2008)[41]\end{array}$ & Epirubicin & 1097 & $\begin{array}{l}\text { metastatic breast } \\
\text { cancer }\end{array}$ & $\begin{array}{l}\text { cumulative dose of } 1000 \\
\mathrm{mg} / \mathrm{m}^{2}\end{array}$ & $\begin{array}{l}\text { Clinical symptoms of } \\
\text { CHF or decline in LVEF > } \\
15 \% \text { from its initial value }\end{array}$ & $11.4 \%$ developed CHF \\
\hline
\end{tabular}

Table 2: Incidence of anthracycline-induced Cardiotoxicity in Several Studies.

The risk factors associated with CICM in our study were found to be dyslipidemia $(\mathrm{r}=.22, \mathrm{p}=.001)$, hypertension $(\mathrm{r}=.12 \mathrm{p}=.05)$, baseline ejection fraction $(\mathrm{r}=-.21 \mathrm{p}=.001)$ and concomitant use of radiation therapy $(\mathrm{r}=.147 \mathrm{p}=.02)$. Dyslipidemia and hypertension are intuitional as they are cardiac risk factors that generally increase the pretest probability of any cardiac event, as does having baseline LVEF dysfunction. Radiation therapy is also well documented to lead to cardiac toxicity [42]. We lacked statistical power to understand the association of CICM with age, gender, beta blocker use, angiotensin converting enzyme inhibitor use, number of chemotherapy cycles or stage of the malignancy. Next steps would include adding patients to our study in order to better understand the cardiac risk African American and Afro-Caribbean patients face undergoing chemotherapy and to develop protective strategies. For example, Gulati et al. found that concomitantly administered candesartan had an overall decline in LVEF of $0.8 \%(95 \%$ CI $-0.4,1.9)$ vs the placebo group with $2.6 \%$ (95\% CI 1.5, 3.8). They did not find any effect of metoprolol on the overall decline in LVEF [43]. Therefore, with better understanding risk factors, such as using concomitant ACE/ARBs, protective strategies can be created to reduce CICM and potentially prevent treatment delays or discontinuation. This is especially important for African Americans, as they are more likely to have CICM than other races.

The racial disparities in the development of CICM are likely multifactorial. Litvak et al. found that the African American populations studied had higher rates of cardiac comorbidities (diabetes, hypertension, hyperlipidemia, and smoking history) [19]. Wheeler et al. found that a higher percentage of African Americans diagnosed with breast cancer have a lack of insurance and a lower socioeconomic status [44]. Finkelman et al. found that African American breast cancer patients undergoing doxorubicin therapy had early alterations in arginine-NO metabolite levels and early biomarker changes that were known to be associated with a greater risk of cardiomyopathy [45]. Therefore, not only social, but also genetic components need further elucidation. This would help potentially guide the development of race specific guidelines, such as increased screening protocols or early referral to cardiology for African Americans treated with trastuzumab or anthracyclines.

Our study had multiple limitations. Firstly, we had a relatively small sample size in a retrospective study with many patients lost to follow up. Secondly, we incorporated data from echocardiograms, which has limited precision and accuracy in measuring LVEF, when compared to the MUGA scan. Thirdly, there was insufficient data on certain patient characteristics, such the number of years since diagnosis of hypertension or hyperlipidemia and adherence with the treatment of comorbidities. Lastly, not all comorbidities were studied, such as the BMI at time of diagnosis. However, this is one of the largest series on the incidence of chemotherapy induced cardiomyopathy among African Americans reported in literature.

\section{Competing Interests}

The authors declare that they have no competing interests.

\section{Acknowledgement}

This work is supported, in part, by the efforts of Dr. Moro O. Salifu M.D., M.P.H., M.B.A., M.A.C.P., Professor and Chairman of Medicine through NIH Grant number S21MD012474.

\section{References}

1. Shakir DK, Rasul KI (2009) Chemotherapy induced cardiomyopathy: pathogenesis, monitoring and management. J Clin Med Res 1: 8-12.

2. Eschenhagen T, Force T, Ewer MS, de Keulenaer GW, Suter TM, et al. (2011) Cardiovascular side effects of cancer therapies: a position statement from the Heart Failure Association of the European Society of Cardiology. Eur J Heart Fail 13: 1-10.

3. Ponikowski P, Voors AA, Anker SD, Bueno H, Cleland JGF, et al. (2016) 2016 ESC Guidelines for the diagnosis and treatment of acute and chronic heart failure: The Task Force for the diagnosis and treatment of acute and chronic heart failure of the European Society of Cardiology (ESC)Developed with the special contribution of the Heart Failure Association (HFA) of the ESC. Eur Heart J 37: 2129-2200. 
Citation: Al-Sadawi M, Singh K, Capric V, Mohiuddin A, Haddadin M, et al. (2020) Incidence and Associated Risk Factors of Chemotherapy-Induced Cardiomyopathy in the African American and Afro-Caribbean Populations. Int J Clin Res Trials 5: 154. doi: https://doi.org/10.15344/2456-8007/2020/154

Page 6 of 6

4. Piper SE, McDonagh TA (2015) Chemotherapy-related Cardiomyopathy. Eur Cardiol 10: 19-24.

5. Sawyer DB (2013) Anthracyclines and heart failure. N Engl J Med 368: 1154 1156.

6. Von Hoff DD, Layard MW, Basa P, Davis HL Jr, Von Hoff AL, et al. (1979) Risk factors for doxorubicin-induced congestive heart failure. Ann Intern Med 91: 710-717.

7. Chen MH, Kerkela R, Force $T$ (2008) Mechanisms of cardiac dysfunction associated with tyrosine kinase inhibitor cancer therapeutics. Circulation 118: 84-95.

8. Onitilo AA, Engel JM, Stankowski RV (2014) Cardiovascular toxicity associated with adjuvant trastuzumab therapy: prevalence, patient characteristics, and risk factors. Ther Adv Drug Saf 5: 154-166.

9. Baron KB, Brown JR, Heiss BL, Marshall J, Tait N, et al. (2014) Trastuzumabinduced cardiomyopathy: incidence and associated risk factors in an innercity population. J Card Fail 20: 555-559.

10. Hasan S, Dinh K, Lombardo F, Kark J (2004) Doxorubicin cardiotoxicity in African Americans. J Natl Med Assoc 96: 196-199.

11. Litvak A, Batukbhai B, Russell SD, Tsai HL, Rosner GL, et al. (2018) Racia disparities in the rate of cardiotoxicity of HER2-targeted therapies among women with early breast cancer. Cancer 124: 1904-1911.

12. Romond EH, Perez EA, Bryant J, Suman VJ, Geyer CE Jr, et al. (2005) Trastuzumab plus adjuvant chemotherapy for operable HER2-positive breast cancer. N Engl J Med 353: 1673-1684.

13. Bowles EJ, Wellman R, Feigelson HS, Onitilo AA, Freedman AN, et al. (2012) Risk of heart failure in breast cancer patients after anthracycline and trastuzumab treatment: a retrospective cohort study. J Natl Cancer Inst 104 1293-1305.

14. Plana JC, Galderisi M, Barac A, Ewer MS, Ky B, et al. (2014) Expert consensus for multimodality imaging evaluation of adult patients during and after cancer therapy: a report from the American Society of Echocardiography and the European Association of Cardiovascular Imaging. J Am Soc Echocardiogr 27: 911-939.

15. Stevens PL, Lenihan DJ (2015) Cardiotoxicity due to Chemotherapy: the Role of Biomarkers. Curr Cardiol Rep 17: 603.

16. Cardinale D, Colombo A, Lamantia G, Colombo N, Civelli M, et al. (2010) Anthracycline-induced cardiomyopathy: clinical relevance and response to pharmacologic therapy. J Am Coll Cardiol 55: 213-220.

17. Early Breast Cancer Trialists' Collaborative Group (2012) Comparisons between different polychemotherapy regimens for early breast cancer: meta-analyses of long-term outcome among 100,000 women in 123 randomised trials. Lancet 379: 432-444.

18. Gianni L, Eiermann W, Semiglazov V, Manikhas A, Lluch A, et al. (2010) Neoadjuvant chemotherapy with trastuzumab followed by adjuvan trastuzumab versus neoadjuvant chemotherapy alone, in patients with HER2-positive locally advanced breast cancer (the NOAH trial): a randomised controlled superiority trial with a parallel HER2-negative cohort. Lancet 375: 377-84

19. Litvak A, Batukbhai B, Russell SD, Tsai HL, Rosner GL, et al. (2018) Racial disparities in the rate of cardiotoxicity of HER2-targeted therapies among women with early breast cancer. Cancer 124: 1904-1911.

20. Crone SA, Zhao YY, Fan L, Gu Y, Minamisawa S, et al. (2002) ErbB2 is essentia in the prevention of dilated cardiomyopathy. Nat Med 8: 459-465.

21. Cameron D, Piccart-Gebhart MJ, Gelber RD, Procter M, Goldhirsch A, et al. (2017) 11 years' follow-up of trastuzumab after adjuvant chemotherapy in HER2-positive early breast cancer: final analysis of the HERceptin Adjuvan (HERA) trial. Lancet 389: 1195-1205.

22. Swain SM, Whaley FS, Ewer MS (2008) Congestive heart failure in patients treated with doxorubicin. Cancer 97: 2869-2879.

23. Piccart-Gebhart MJ, Procter $M$, Leyland-Jones B, Goldhirsch A, Untch $M$ et al. (2005) Trastuzumab after Adjuvant Chemotherapy in HER2-Positive Breast Cancer. N Engl J Med 353: 1659-1672.

24. Rugo HS, Brufsky AM, Ulcickas Yood M, Tripathy D, Kaufman PA, et al (2013) Racial disparities in treatment patterns and clinical outcomes in patients with HER2-positive metastatic breast cancer. Breast Cancer Res Treat 141: 461-470.

25. Vogel CL, Cobleigh MA, Tripathy D, Gutheil JC, Harris LN, et al. (2002) Efficacy and safety of trastuzumab as a single agent in first-line treatment of HER2-overexpressing metastatic breast cancer. J Clin Oncol 20: 719-726.
26. Guarneri V, Lenihan DJ, Valero V, Durand JB, Broglio K, et al. (2006) LongTerm Cardiac Tolerability of Trastuzumab in Metastatic Breast Cancer: The M.D. Anderson Cancer Center Experience. J Clin Oncol 24: 4107-4115.

27. Suter TM, Procter M, van Veldhuisen DJ, Muscholl M, Bergh J, et al. (2007) Trastuzumab-associated cardiac adverse effects in the herceptin adjuvant trial. J Clin Oncol 25: 3859-3865.

28. Perez EA, Suman VJ, Davidson NE, Sledge GW, Kaufman PA, et al. (2008) Cardiac safety analysis of doxorubicin and cyclophosphamide followed by paclitaxel with or without trastuzumab in the North Central Cancer Treatment Group N9831 adjuvant breast cancer trial. J Clin Oncol 26: 12311238.

29. Untch M, Muscholl M, Tjulandin S, Jonat W, Meerpohl HG, et al. (2010) Firstline trastuzumab plus epirubicin and cyclophosphamide therapy in patients with human epidermal growth factor receptor 2-positive metastatic breast cancer: cardiac safety and efficacy data from the Herceptin, Cyclophosphamide, and Epirubicin (HERCULES) trial. J Clin Oncol 28: 14731480.

30. Slamon D, Eiermann W, Robert N, Pienkowski T, Martin M, et al. (2011) Adjuvant trastuzumab in HER2-positive breast cancer. N Engl J Med 365: 1273-1283.

31. Romond EH, Jeong JH, Rastogi P, Swain SM, Geyer CE Jr, et al. (2012) Seven-year follow-up assessment of cardiac function in NSABP B-31, a randomized trial comparing doxorubicin and cyclophosphamide followed by paclitaxel (ACP) with ACP plus trastuzumab as adjuvant therapy for patients with node-positive, human epidermal growth factor receptor 2-positive breast cancer. J Clin Oncol 30: 3792-3799.

32. Azambuja E, Procter MJ, Veldhuisen DJv, Agbor-Tarh D, Metzger-Filho $O$ et al. (2014) Trastuzumab-Associated Cardiac Events at 8 Years of Median Follow-Up in the Herceptin Adjuvant Trial (BIG 1-01). J Clin Oncol 32: 21592165.

33. Advani PP, Ballman KV, Dockter TJ, Colon-Otero G, Perez EA, et al. (2016) Long-Term Cardiac Safety Analysis of NCCTG N9831 (Alliance) Adjuvant Trastuzumab Trial. J Clin Oncol 34: 581-587.

34. Yoon HJ, Kim KH, Kim JY, Park HJ, Cho JY, et al. (2016) ChemotherapyInduced Left Ventricular Dysfunction in Patients with Breast Cancer. J Breast Cancer 19: 402-409.

35. Dang C, Guo H, Najita J, Yardley D, Marcom K, et al. (2016) Cardiac Outcomes of Patients Receiving Adjuvant Weekly Paclitaxel and Trastuzumab for Node-Negative, ERBB2-Positive Breast Cancer. JAMA Oncol 2: 29-36.

36. Horenstein MS, Vander Heide RS, L'Ecuyer TJ (2000) Molecular basis of anthracycline-induced cardiotoxicity and its prevention. Mol Genet Metab 71: 436-444

37. Wouters KA, Kremer LC, Miller TL, Herman EH, Lipshultz SE, et al. (2005) Protecting against anthracycline-induced myocardial damage: a review of the most promising strategies. Br J Haematol 131: 561-578.

38. Hasan S, Dinh K, Lombardo F, Kark J (2004) Doxorubicin cardiotoxicity in African Americans. J Natl Med Assoc 96: 196-199.

39. Jensen BV, Skovsgaard T, Nielsen SL (2002) Functional monitoring of anthracycline cardiotoxicity: a prospective, blinded, long-term observational study of outcome in 120 patients. Ann Oncol 13: 699-709.

40. Azambuja $E$, Paesmans $M$, Beauduin $M$, Vindevoghel A, Cornez $N$ et al. (2009) Long-Term Benefit of High-Dose Epirubicin in Adjuvant Chemotherapy for Node-Positive Breast Cancer: 15-Year Efficacy Results of the Belgian Multicentre Study. J Clin Oncol 27: 720-725.

41. Ryberg M, Nielsen D, Cortese G, Nielsen G, Skovsgaard T, et al. (2008) New Insight Into Epirubicin Cardiac Toxicity: Competing Risks Analysis of 1097 Breast Cancer Patients. J Natl Cancer Inst 100: 1058-1067.

42. Hufnagle JJ, Goyal A (2020) Radiation Therapy Induced Cardiac Toxicity. Stat Pearls. Treasure Island (FL): StatPearls Publishing.

43. Gulati G, Heck SL, Ree AH, Hoffmann P, Schulz-Menger J, et al. (2016) Prevention of cardiac dysfunction during adjuvant breast cancer therapy (PRADA): a $2 \times 2$ factorial, randomized, placebo-controlled, double-blind clinical trial of candesartan and metoprolol. Eur Heart J 37: 1671-1680.

44. Wheeler SB, Reeder-Hayes KE, Carey LA (2013) Disparities in breast cancer treatment and outcomes: biological, social, and health system determinants and opportunities for research. Oncologist 18: 986-993.

45. Finkelman BS, Putt M, Wang T, Wang L, Narayan H, et al. (2017) ArginineNitric Oxide Metabolites and Cardiac Dysfunction in Patients With Breast Cancer. J Am Coll Cardiol 70: 152-162. 